\title{
Omkring Grundtvigs historieskrivning - status og fremtidsperspektiver
}

\author{
Af Sigurd Aa. Aarnes
}

Grundtvig var opptatt med historiske studier og historiske fremstillinger store deler av sitt liv.

Dels dreier det seg om korte, elementære læreböker og historiske huskerim som »En liden Bibelkrönike for Börn og Menigmand« fra I8I4 og »Krönike-Rim til levende Skolebrug« fra I829. Dels er det större oversiktsfremstillinger som de tre verdenskröniker av I8I2, I8I4 og I8I7 og Gr.s historiske hovedverk, den monumentale »Haandbog i VerdensHistorien« i 3 bind fra $1833-1843$. Dels har vi å gjöre med poetiske fremstillinger som det danmarkshistoriske »Roskilderim « fra I8I2 (utgitt 1814) og det kirkehistoriske »Christenhedens Syvstjerne« fra I850årene. Videre har vi Gr.s kirkehistoriske hovedverk »Kirkespejl« fra I 86 I-3, kåserier som de historiske samtaler med damene I839-1844 og hans samtidshistorie, Mands-Minde-foredragene fra 1838 - for ikke å tale om Gr.s viktigste bidrag som historieforsker, hans forskjellige vitenskapelige utgaver og oversettelser av det angelsaksiske Beowulf-kvadet. Til dette kommer Gr. oversettelser av Snorre Sturlasons Heimskringla og Saxos Danmarkshistorie og forskjellige utrykte historiske skrifter som forskningen ennå ikke har utnyttet - f. eks. de over hundre talene som Gr. holdt i »Danske Samfund « fra I839 og følgende år og de verdenshistoriske foredrag i »Den danske Forening « i I 855, samlet i fsc. 37 i Grundtvig-arkivet. - Som den sakkyndige vil vite, er selv ikke denne imponerende listen fullstendig.

Kvantitativt har da Gr. bare som historiker etterlatt seg et usedvanlig livsverk. Likevel er det merkelig hvor lite historikeren Gr. ruver i hans ettermæle. Går vi til en håndbok som Ellen Jörgensens »Historiens Studium i Danmark i det 19. Aarhundrede« (Kbh. 1943), vil vi se at hun berömmer Gr. som en »Pioner i Beowulf-Forskningen« (39) og har mye

*) Innlegg ved forskerstevnet på Sandbjerg 3o.8.64. 
godt å si om hans Håndbog i Verdens-Historien: Den er »et selvstændig Værk, et modigt Forsög, paa sin Vis et förste Forsög « (40), den er »det Værk, der rakte videst« av alle danske historieverk i förste halvdel av det 19. århundre, »mægtig i Anlæg og dybt personligt, en Kilde, hvoraf hans Disciple ned gennem Aarene øste Viden og Styrke og stadig Fornyelse under deres folkeopdragende Virke« $(64)$.

Men til tross for denne velvillige bedömmelsen har Ellen Jörgensen ikke spandert mer enn vel 7 sider på sin sammenhengende fremstilling av historikeren Gr., og han er ikke kommet med på listen over »enkelte Forskerpersonligheder « som hun i siste del av sin bok ofrer egne kapitler til mer inntrengende personlig karakteristikk av.

Når man på denne måten ofte har gått lett hen over historikeren Gr., kan vel årsakene være forskjellige. Dels har vel hans innsats som historiker kommet i skyggen av alt det andre han var: salmedikter, kirkepolitiker, forkynner, mytolog, filolog, pedagog osv. Dels må vi ikke glemme at Gr. i hele sin legning og interesse som historiker går på tvers av hovedtendensen innenfor det 19. århundres historievitenskap. Det 19. århundre, særlig århundrets 2. halvdel, er den positivistiske historieskrivnings æra. Målet er det faktiske, »wie es eigentlich gewesen«, for å bruke Leopold von Rankes berömte ord. Det er ikke vanskelig å se hvordan Gr. med hele sitt subjektive og affektive forhold til historien måtte komme i motsetningsforhold til samtidens kritiske historievitenskap.

Gr. var jo ikke historiker i moderne, faglig forstand og har heller ikke gitt seg ut for å være det. Han er historieforteller og historiefilosof. Som historiker er han ikke först og fremst ute for å fastslå faktiske saksforhold. Overfor samtidens kildekritikk forholder han seg suveren. Vi må forstå fortiden »efter den levende Formel vi har i os selv, og efter vor velforstaaede Egen-Nytte«, skriver Gr. i »Nordens Mythologi«, I832, »thi det kan aabenbar være os det Samme, hvad de gamle Helte hedd... naar vi kun har Gavnet deraf, ligesom det kan være os det Samme, hvem der gjorde Völuspa, naar vi kun forstaae den, kan være os det Samme, hvordan Livet var deelt i Old-Tiden, naar vi blot kan tilegne os det ...« (org. utg. 144-5). Om Kalmarunionen kan Gr. fortelle sine tilhörerinner på Amalienborg slott at den mislyktes »og det nytter da ikke stort at gruble over Aarsagerne, undtagen forsaavidt vi derved kunde lære, hvordan det store Øjemed virkelig lader sig opnaa (»Historiske Foredrag I839-1844《, s. I06). »Man har ... trættedes ... om ... Kædmunds Parafras er ægte eller ikke, men det er ikke Umagen 
værd,« heter det i den samme forelesningsrekken, »thi enten vi har Bogen af Kæmunds Vers eller ikke, var de dog lige mærkværdige og gjorde lige meget Gavn i deres Tid, og om de skriftlige Levninger, vi har fra forrige Tider, er det egentlige Spörgsmaal, om de duer noget; thi mange gamle Böger er ægte nok for saa vidt, men fortjene ikke at læses (HF.38). Nei, lærde petitesser av dette slag - »Mandtal og Aarstal og Navnetal og Afstanden paa en Prik baade i Tiden og Rummet og Fuldstændigheden af alt, hvad der ikke er værd at nævne« - overlater Gr. gladelig til de »grundige Historikere« (HF.136,77).

Den som kjenner Gr. historiske forfatterskap, vil vite at det overalt vrimler av resonnementer av denne typen. Overalt vil han gi oss sitt $\gg$ Smule Forhold ... til de store Verdens-Begivenheder ... Om nu det kan gaa an ... for Historien og Objektiviteten ... det tager jeg tröstig paa min Samvittighed ...«, som det heter i innledningen til Mands Minde-foredragene (Mands Minde, I4). »... den evige Kriticeren udtömmer den menneskelige Livskraft og giver derved de dyriske Drifter ... frit Spillerum ... Videnskaben er ene til for ... Menneske-Livets Skyld og maa altsaa hverken drives eller fremmes paa Livets Bekostning, men kun til dets Tjeneste, til dets Oplysning og Fordel, dets Forklaring og Forskjönnelse ...«, dekreterer Gr. i den samme foredragsrekken (MM.96-97).

Hva mon Leopold von Ranke ville sagt til slike ord? Det er ikke vanskelig å se avstanden mellom en subjektiv og folkepedagogisk historieskrivning av Gr. type og den positivistiske historievitenskap som i Gr. levetid erobret Europas universiteter. Den dödsdom over historike-

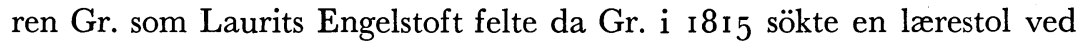
Köbenhavns universitet, og som Michelsen opptrykker i »Tilblivelsen af Gr. Historiesyn« (s. 28), er symptomatisk for dette motsetningsforhold og kunne for så vidt like gjerne være skrevet i dag.

Jeg tror ikke det i dag er Gr. forskningens oppgave å rehabilitere Gr. som faghistoriker overfor denne dom; det lar seg simpelthen ikke gjöre. Når vi unntar Gr. innsats i Beowulfforskningen, må vi slå fast at han i sin behandling av det historiske kildemateriale ofte ikke en gang når opp til de krav hans samtid stilte, langt mindre til moderne krav. Sett fra et isolert faglig, metodologisk synspunkt er Gr. historieskrivning (igjen bortsett fra hans Beowulfforskning) foreldet, knyttet som den er til tradisjonssammenhenger med den lutherske ortodoksis, rasjonalismens og romantikkens historieskrivning. Interesserer Gr. i dag som historiker, så må det åpenbart være på andre premisser enn de faglige. 
At utgangspunktet ikke er det faglig-historiske, er da også tydelig hvis man går til det moderne hovedverk om Gr. historieskrivning: Michelsens to-bindsverk om tilblivelsen av Gr. historiesyn fra I950-årene. Utgangspunktet er her rent aktuelt, til å begynne med bestemt av den 2. verdenskrig: Hva kan vi i dag i vår kultursituasjon lære av Gr. kritikk av den kultursituasjon som forelå i hans samtid? Gr. reagerte, hevder Michelsen, overfor de förste spirer til en kulturkrise som i dag har nådd sitt kritiske stadium (se f. eks. Gr. Stud. I95 I, I00): Gr. »har fængslet mig selv så stærkt, at jeg kunde finde idékampen för og under den 2. verdenskrig genspejlet deri (dvs.: i de 3 verdenskröniker). For hvad var det, der forførte mange mennesker dengang til at slutte sig til nazismens ideologi, om ikke en forfalsket genklang af den tyske romantik? I denne situation fik man brug for en mand, der kendte den tyske romantiske idealisme, selv havde været grebet deraf og derfor kendte farerne derved fra sit eget sind. En sådan mand var Gr. Den gradvis opdagelse heraf genspejles i de tre Verdenskröniker, og det er efter min mening derfor, de vedkommer videnskaben også i dag ... For mig har det afgørende problem været, om Gr.s tanker om kulturlivet har interesse for moderne mennesker, og i bekræftende fald hvorfor ...«. (Michelsen i Gr. Stud. I 962, 53, 55).

Tydeligere kan det ikke uttrykkes at verdenskrönikene ikke lenger interesserer som verdenshistoriske fremstillinger, men som kulturkritiske skrifter. Med denne aksentforskyvning föler Michelsen med én gang Gr. verdenskröniker som aktuelle, talende rett inn $\mathrm{i}$ vår egen situasjon.

Om det må være meg tillatt å nevne min egen bok fra ig6i om »Historieskrivning og livssyn hos Gr.« som et annet eksempel på den samme dreining av interessen fra det faglig-historiske til andre synspunkter, så var utgangspunktet for mine studier fölgende rent metodologiske spörsmål: Hvordan går det til at en historikers livssyn strukturerer hans historieskrivning? I denne sammenheng hadde igjen verdenskrönikene interesse, for det er få steder man tydeligere kan studere hvordan et livssyn bestemmer en historieskrivning enn nettopp her.

Verdenskrönikene - og det gjelder Gr. historieskrivning som helhet må med andre ord $\mathrm{i}$ dag finne seg $\mathrm{i}$ a bli lest og vurdert som noe annet og mer enn verdenshistoriske oversiktsfremstillinger. Gr. historieskrivning er blitt idéhistoriske tekster, interessante ikke ved det de forteller om verdenshistorien, men ved det de forteller om Gr. selv og hans samtid. Dette er en perspektivendring som all eldre faglitteratur ser ut til å være underlagt, om det nå gjelder Georg Brandes’ litterære kritikk, Holbergs kirkehistorie eller Sigmund Freuds psykoanalyse. 
I denne forstand blir da Grundtvigforskningen - som all idéhistorisk forskning - en samtale mellom nåtiden og fortiden. Ser vi ut over den Grundtvigforskning som har blitt til etter den 2. verdenskrig, synes vi å merke denne samtalen nesten overalt: Faren er naturligvis at det aktuelle utgangspunktet kan komme til å bestemme resultatet. I sin tale ved Gr. grav på Køge ås sa Björnstjerne Björnson at mens det ved andre graver lyses fred »bör det lyses Kamp over denne. Kamp for det, vi elske, og elske ved ham«. For en ikke-dansk som har stått fjernere fra det kampgny som i Gr. hjemland har stått av »den Gamles« navn, kan det synes som om vel mye av dette kampgny av og til har gitt ekko i Gr.forskningen, og at dette kan ha svekket deler av den metodisk. Men på den annen side har denne nære sammenheng mellom personlig livsholdning og forskning fört det med seg at det er lite av Gr. forskningen som er kjedelig, det er engasjerte og til sine tider inspirerte menn som har skrevet.

Men for hvem? Ejnar Thomsen berörer det man litt höytidelig kanskje kunne kalle Gr.forskningens tragikk når han i sin opposisjon ved Toldbergs disputas (trykt i Gr. Stud. 1952) sier at til tross for at doktoranden skriver »ud fra en moderne litteraturvidenskabelig metode og først og fremmest med henblik på forskere, som er fremmede for Gr.forskningens særlige problematik«, så »bliver (det) vel overhovedet hans store Gr.bogs tragik at den ifølge sin metode og sin terminologi sigter på læsere der gennemgående kan påregnes at stå Gr. tankebaner fjernt, men ifølge metodens personlige variation (det dominerende substrathensyn) alleregentligst appellerer til 'grundtvigianere' ...« (Gr. Stud. I952, 89).

At det å falle mellom to stoler på denne måten er Gr.forskningens situasjon i mitt hjemland, er jeg ikke i tvil om. Jeg tar Ejnar Thomsens ord som et indisium på at situasjonen heller ikke er ukjent i Gr. eget land. Bak mye av den moderne Gr.forskning etter den 2. verdenskrig synes det å ligge en prisverdig vilje til å bryte ut av en tidligere sektmessig isolasjon som synes å ha sperret adgangen for mange til Gr. forfatterskap. Denne vilje til å plassere Gr. innenfor det almene kulturmiljö med åndsvitenskapens vanlige metoder er tydelig når Höirup i sin disputas presenterer Gr. som en filosof blant filosofer, når Albeck og Toldberg behandler Gr. diktning med de verktöy moderne litteraturvitenskap har gitt dem, og når Michelsen gjör Gr. til en av dem som först har analysert grunntrekkene $\mathrm{i}$ vår kulturkrise.

Når vi ser tilbake på den staselige rekken av studier som Gr. Selskapet har utgitt, synes tiden å være kommet til å spörre: I hvilken grad har 
det egentlig lykkes oss å bryte isolasjonen? Når jeg tenker på den veldige ökning og intensivering av vår viten om $\mathrm{Gr}$. tanker som er skaffet til veie $\mathrm{i}$ tiden etter den 2. verdenskrig, og hvor forholdsvis kort vår skriftserie og Gr. Studier når, har jeg spurt meg selv om tiden nå ikke er kommet til å ta et krafttak for å presentere noe av den innsikt vi har nådd frem til, i en lettere tilgjengelig form. Skulle det være utenkelig at man skulle kunne få en av de glimrende danske pocketbokserier interessert $i$ et bind essaysamlinger om forskjellige felter av Gr. tankeverden ved kompetente spesialister? Vi må se $\mathrm{i}$ öynene at fremtidens bokproduksjon synes å være pocketboken. Bredere og bredere kretser blir vant til å skaffe seg sin lesning på denne måten. Et initiativ som dette skulle ligge godt $\mathrm{i}$ tråd med Gr. Selskapets oppgave.

Av Gr. historiske forfatterskap er det ennå bare verdenskrönikene som kan sies å være gjort til gjenstand for et bredt vitenskapelig studium. Forskjellen mellom Michelsens og mitt arbeide er delvis metodisk genetisk kontra systematisk metode - dels er det et motsetningsforhold i synet på Gr. forhold til den tyske romantikk som han mötte i huslærerårene på Langeland: Satte romantikken avgjörende, varige spor slik at det vil være riktig å si at $\mathrm{Gr}$. preges av romantikken for livet, eller betyr det kristne gjennombrudd I8Io-I I et farvel til romantikken og alt dens vesen, slik at $\mathrm{Gr}$. fra nå av bör karakteriseres som kristen og ikke som romantiker? Jeg går i min bok inn for det förstnevnte synspunkt; Scharling og - enda mer bestemt - Michelsen går inn for den sistnevnte oppfatning.

Det forekommer meg at dette spörsmålet - som så mange andre problemer innenfor Gr.forskningen - har kommet inn i en ny fase etter Thanings avhandling »Menneske först $\ll$. Et av de mange biprodukter av dette arbeidet er Thanings påvisning av det en kunne kalle en »oppromantisering « hos Gr. omkr. I823-4. Ved påsketider I824 gjenoppfrisker Gr. Steffens' filosofiske forelesninger (33). Thaning taler om »romantikkens genoplivelse ved Irenæus« hos Gr. på denne tid (36). ».. romantikken og Irenæus bidrager hver fra sin side til den bestemmelse af mennesket, som for Gr. står fast livet ud ...« (4I). Om Gr. »Literaire Testamente« ( 1827 ) siger Thaning at »hans mytologiske ungdom《 her har »fået en virkelig renæssance under hans opgör med sig selv« (49). I824 er for Thaning Gr. »stærkt romantiske prædikantperiode« (96). Også Gr. gjennombrudd som salmedikter i 1832 setter Thaning $\mathrm{i}$ forbindelse med »en ny opblussen af romantikkens indfly- 
delse på hans sind ...«. Gr. nye salmediktning »præges af, at Gr. er romantikkens lærling« $(580)$.

Det forekommer meg at Thaning ved sin dokumentasjon har lagt et fastere fundament under Scharlings tese om en »stigende romantisk Linie« hos Gr. fra 1820-årene av (»Gr. og Romantikken«, s. 244). Scharling har her - etter min mening - fornemmet noe riktig, selv om han ikke fikk anledning til å underbygge sin tese.

Spörsmålsstillingen Gr. og den tyske romantikk er vesentlig, ikke bare for Gr. forskningen, men - via hans innflytelse - for dansk og nordisk åndsliv i det hele i det i9. århundre. Det er imidlertid en svakhet ved Thanings avhandling - som ved andre bidrag til denne debatt - at han i så liten grad definerer hva han mener når han bruker betegnelsen »romantisk «. Skal diskusjonen om Gr. og romantikken ikke gli ut i en skinnfektning, tror jeg det blir nödvendig å löse spörsmålet opp i konkrete og avgrensede underspörsmål. »Romantisk « og »kristen« er altfor omfattende sekkebetegnelser til vitenskapelig bruk. Först etter at man har plassert Gr. i forhold til en rekke klart definerte kriteria, kan man våge seg på å felle en samlet dom om forholdet mellom det »kristne« og det »romantiske« $\mathrm{i}$ hans tankeverden. Jeg tror at ved en slik mer omhyggelig fremgangsmåte vil en del av de rådende motsetningsforhold i debatten om Gr. og romantikken avslöre seg som skinnuenighet.

Den oppgaven som jeg i dag synes frembyr seg som den störste og vesentligste innenfor studiet av Gr. historiske forfatterskap, er vel å få en skikkelig analyse av hans historiske hovedverk, »Haandbog i VerdensHistorien«. Håndbogen er i volum og i den arbeidstid Gr. har nedlagt i den, et av hans störste litterære krafttak nest etter Sangverket. Holger Begtrup betraktet den som et så sentral verk at han spanderte 2 av Io bind i Gr. Udvalgte Skrifter på et opptrykk av Håndbogen. Her finner man Gr. ferdig utformede historieoppfatning, her har han vist hva han kunne yte som historieforteller på höyden av sin kraft. För vi virkelig kjenner Håndbogen, kan vi ikke si at vi kjenner Gr. som historiker.

Et förste problem må her nödvendigvis bli forholdet mellom verdenskrönikene på den ene siden og Håndbogen på den andre siden. Har vi å gjöre med et brudd eller en fortsettelse? Gr. har selv lagt hovedvekten på bruddet når han i forordet til Håndbogen (US. VI, I I-I 2) stiller opp mot hverandre det han kaller sin hebraiske historieskrivning i verdenskrönikene kontra den greske i Håndbogen. Dette overflödiggjör naturligvis ikke en undersökelse. De to forskere som hittil har dröftet 
spörsmålet, har kommet til stikk motsatte resultater. Thaning henholder seg i sitt kapitel om Håndbogen til Gr. oppfatning, som jo faller godt i tråd med hans egen tese. Det viktigste avsnitt i Thanings kapitel om Håndbogen heter betegnende nok »Sekulariseringens fölger $\mathrm{i}$ håndbogen «. På den annen side står Michelsen som hevder at Gr.s historiesyn var det samme i I833 som i I8I2, I8I4 og I8I7, »men hans mening om, i hvilken grad det lod sig videnskabeligt praktisere, har forandret sig fra bog til bog « (»Tilblivelsen af Gr. historiesyn«, s. 4I-2). Her kan bare en dyptgående analyse av Håndbogen gi svar.

En undersökelse av Håndbogen burde vel sette inn mot det grunnleggende begrepsapparat som Gr. fremstilling er bygd over. Jeg tenker på slikt som den gjennomgående parallellisering mellom menneskelivets faser - barndom, ungdom, manndom og alderdom, hver med sitt psykologiske særpreg - og historiens epoker: oldtiden som ungdommens og innbilningskraftens tid, middelalderen som manndommens og fölelsens og den nyere tid som alderdommens og forstandens, et skjema som alt er antydet i Gr. landemodetale »Om Udsigterne for Christi Kirke« fra sommeren I8I4 (se US.III,54). Jeg tenker videre på den like gjennomförte oppdeling av det menneskelige kulturliv i feltene kirke, stat og skole, som henholdsvis går på menneskets forhold til Gud, til hverandre og til seg selv. Også dette skjema kan spores langt tilbake i Gr. forfatterskap - iallfall til Danne-Virkeavhandlingene.

I det hele tatt er en rekke av Gr. grunnbegreper konstituerende for historiefremstillingen i Håndbogen. Det gjelder begreper som liv og död (romerne er naturligvis behersket av »Dödens Aand «!), sannhet og lögn, forklaring, »Universalhistorie«. En undersökelse for seg krever forsynsbegrepet som er av de begreper som hyppigst benyttes og igjen og igjen spiller en sentral rolle i fremstillingen. Så sentralt står det at det er problematisk om Håndbogen virkelig er så gresk eller sekularisert som Gr. og Thaning vil ha det til.

Et interessant punkt i Håndbogen er Gr. positive vurdering av middelalderen som »den ny Skabelse« (US.VI,5 I I). Synspunktet kan virke helt moderne for en som har studert historie i vår tid; $\mathrm{i}$ dag legger jo faghistorikerne sterk vekt på den ubrutte kontinuitet fra romersk keisertid til middelalderens föydalsamfunn. Den siste samlede fremstilling av europeisk middelalderhistorie som vi har fått hos oss i Norge (av Johan Schreiner), heter betegnende nok for dette syn »Tusen års grotid «. Det springende punkt for Gr. i middelalderens historie er angelsakserne som formidlere mellom den gamle folkekrets rundt Middelhavet og den nye 
rundt Østersjöen. På denne måten er de for Gr. bærere av historiens ubrutte kontinuitet. Angelsakserne ble »Stamfædre til den ny Kristenhed « fordi de tilegnet seg evangeliet på morsmålet »i Forbindelse med sin ejendommelige Tankegang og hele Folkelighed « (»Krönike-Rim«, Kbh. 1875, LXI). At angelsakserne lot seg döpe og påtok seg denne megler-rolle, er for Gr. »den störste af alle Middelalderens Begivenheder, og Bedas Kirke-Historie paa Angelsaxisk er Traaden i dens Labyrint« (s. st. LXII). Vi ser hvordan Gr. hele tiden innarbeider sine sentrale begreper - i dette tilfelle det levende ord og morsmålet - i sin historiefremstilling.

Et problem som jeg ikke har sett noen ta opp, men som nok kunne kreve sin belysning, er det idéhistoriske emne som ligger i spörsmålet om lengdevirkningene av Gr. historiske forfatterskap. Få av hans historiske skrifter ble vel de folkeböker han hadde drömt om. Det skrift som i så måte synes å ha nådd lengst, er kanskje Gr. Saxo-oversettelse. Ellen Jörgensen forteller i »Historiens Studium i Danmark i det i 9. århundrede«: »Atter og atter finder man i Levnedstegninger og Breve ned gennem Aarhundredet Vidnesbyrd om hvor stærkt den har virket paa unge friske Sind « (37). Saxo-oversettelsen er da også - så vidt jeg vet - det förste av Gr. historiske arbeider som har tatt spranget inn i pocketbokalderen (som trebindsutgave i Hasselbachs serie 1962).

Iallfall til inn i I880-90-årene har Gr. Håndbog og »historiekartet《 »Tidens Ström« vært blant de viktigste hjelpemidler for de danske folkehöyskolers historielærere (jfr. Roar Skovmand: »Folkehöjskolen i Danmark I84I-I892《, Kbh. I944, 64, 66, 73-4, Ioo, 26 I). Noen av Gr. elementære læreböker $\mathrm{i}$ historie fikk en forholdsvis vid spredning og holdt seg merkelig lenge i bruk. »En liden Bibelkrönike for Börn og Menigmand « av 1814 oppnådde f. eks. 3 utgaver i Danmark og Sverige og I norsk og finsk utgave i löpet av det I9. århundre. Gr. lille »Historisk Börne-Lærdom《 - opprinnelig skrevet som innledning til »KrönikeRim«, I829 - opplevde hele 9 opplag fra 1829 til I89o og ble i $1880-$ årene oversatt til finsk. Kartet »Tidens Ström eller universal-historisk Omrids« kom så sent som i igi6 ut i sin 6. utgave osv.

Men virkningen av $\mathrm{Gr}$. historiske forfatterskap vil ikke kunne måles bare ved å oppregne utgaver og opplagstall - ja, vel ikke en gang först og fremst på denne måten. Vi må ikke glemme at historikeren Gr. på så mange måter ble en inspirator og igangsettende kraft i Danmark. Han kom til å prege en hel generasjon av historiske skribenter - menn som Fr. Hammerich, L. Helweg og Fr. Barfod. Vi kan også tenke på 
impulsen fra Gr. i organisasjonstiltak som »Danske Samfund « (stiftet I839), »Selskabet for Danmarks Kirkehistorie《 av I849 og »Selskabet til fremmede Kildeskrifters Overförelse til Modersmaalet« fra I875. For ikke å tale om den betydning han har hatt for historieoppfatningen og historiefortellingen i danske og nordiske folkehöyskoler, iallfall $i$ et par generasjoner til opp mot slutten av det 19 . århundre!

I folkehöyskolen ble historie et hovedfag. Ja, for mange grundtvigianere var folkehöyskolen like frem »den historiske Højskole«, noe som avspeiler seg $\mathrm{i}$ det forhold at historieundervisningen hadde en meget bredere plass ved de utpreget grundtvigianske folkehöyskoler $\mathrm{i}$ forhold til i de andre (jfr. Skovmand, s. 259). Når det gjelder historieundervisningen på folkehöyskolene, var det lenge slik - for å uttrykke det med Roar Skovmand - at »Verdenshistorien - det var 'Tidens Ström', saadan som Gr. havde tegnet den; Mytologien, - det var Nordens Sindbilledsprog, saadan som Gr. havde tolket det ... der (er) ikke nogen enkelt Mand, der har paavirket Højskolens Arbejde, baade dets Form og Indhold, stærkere end Gr. ...« (Skovmand, s. 425, 416).

Og er det nå så helt sikkert at tradisjonen er utdödd? Jeg synes jo nok jeg kan höre gjenklangen av en kjent röst når jeg i »Et Forord for Voksne om Folkets Danmarkshistorie« av Martin A. Hansen i hans posthume bok »Af Folkets Danmarkshistorie« leser om historien at den er en »Del af vor Eksistens ... vi er, opdager vi, med i et stærkere, dybere Fællesskab, det danske Folk, hvis Grundvold er Modersmaalet, Danmarkshistorien, Digtningen ... Skræp maa graves op, ikke for at beskrives, pollenanalyseres og stilles på Museum, men for at bruges« (7). Ordene kunne jo - bortsett fra det mer moderne vokabular - skrive seg fra Gr. hånd! Den samme levende forbindelse bakover synes jeg å spore når Martin $\mathrm{A}$. Hansen $\mathrm{i}$ forordet til »Orm og Tyr« priser sin barndoms historiske skribent, nordmannen Nordahl Rolfsen, som en »dilletant $\mathrm{i}$ faget, en virkelig historieforteller «.

Alt det jeg her har nevnt, mener jeg kan hjelpe til å gi svar på spörsmålet om hvordan og i hvilken utstrekning Gr. har vært med på å skape det man kunne kalle det danske folks historiske myter. Med en historisk myte mener jeg en tolkning av et folks historie som er så omfattende at den tilstreber å gi svar på spörsmål som disse: Hva er nasjonens eksistensberettigelse som eget folk? Hva er det som skiller dansk historie ut fra alle andre folks historie?

Det er naturlig for meg som nordmann å stille spörsmålet på denne måten. I norsk historie har slike myter spilt en ikke liten rolle. Vi har 
hatt våre nasjonale myter om Norge som »Kiæmpers Födeland «, om sammenhengen mellom det gamle og det nye Norge med unionstiden imellom som den »uekte lodning « - som Wergeland kalte det - og disse myter har spilt en viktig rolle som fundament for norsk selvhevdelsespolitikk overfor Sverige i det I9. århundre. Det finnes i dag mange eksempler på at ikke-europeiske folk som trer inn i rekken av de selvstendige nasjoner, söker å skape sine nasjonale myter (jfr. det franske begrep »negritude«). Kan Gr. oppfatning av danskene som det kjærlighetsfulle $\gg$ Hjertefolk« $\mathrm{i}$ denne forstand ha hatt noe å si for danskers syn på seg selv og sin nasjonale egenart? Kan det påvises om Gr. forskjellige optimistiske spådommer om Danmark, f. eks. i »Christenhedens Syvstjerne«, i noen sammenheng har vært en inspirasjonskilde i dansk historie?

Det sier seg selv at idéhistorie på denne måten er et vanskelig arbeidsfelt der feilkildene er mange og farlige. En forsker som tar opp spörsmål av denne art, må vite hva han gjör. Han må klart definere den forestilling han vil studere og nöye studere utbredelsesveiene fra Gr. inn i det danske kultursamfunn.

Det kunne naturligvis være mange flere oppgaver å nevne. La meg bare til slutt streife Gr. som kulturkritiker. Det er jo nettopp i det historiske forfatterskap Gr. utfolder seg mest strålende i så henseende. På dette område har han hatt et merkelig sikkert instinkt. Jeg tenker f. eks. på hans forskjellige skarpsynte analyser av tysk vesen og av farene ved en tysk rikssamling fra VK. I8I 7 og fremover, bl. a. i »Mands Minde«. Et samlet Tyskland »vilde med den tyske Stridbarhed, Skarpsindighed og Stolthed, under $\sin$ Napoleon ... paalægge Verden de tungeste Lænker, den endnu har baaret« (Mands Minde, s. 38I). Og hvem av oss trenger ikke i dag å lytte til Gr. tale om industrialismens skyggesider: »Maskineriet ... (som) gjör Mennesker i Tusendtal ... til lutter Biting, lutter Appendixer til Maskineriet som Hovedsag og Grundkraft ...«. (s. st. s. 446) »Fremtidsstemmen« hos Gr. kan ofte forbause en. Det ligger en rekke emner av denne type og venter, der nettopp Gr. historiske skrifter vil kunne gi mye, og der det nok skal vise seg at Gr. ikke er så uaktuell som den utenforstående iakttager vil tro.

Det skal ikke nektes at den som gir seg i kast med Gr., ikke velger den minste motstands vei. Jeg er enig med Ejnar Thomsen $\mathbf{i}$ at det over deler av Gr. forfatterskap - det gjelder vel særlig den eldre Gr. - er noe »rutinemæssigt stivnet« (Gr. Stud. I952, 87) - jeg ville legge til: 
noe formelfast, en nesten monoman gjentagelse av de samme yndlingsideer med de samme ord. Men så - midt i det tilsynelatende örkenlandskap - heves vi opp til det vide utsyn, og det tales til oss om menneskelivet og kristenlivet av en röst som er ingen annens og ut fra en innsikt som er ingen annens. Gr. er uuttömmelig. Han tilhörer - med Martin A. Hansens ord i »Leviathan« - »det vordende, han gaar ud over Protestantismen, og hos ham synes en Kultur at ligge i Svøb« (Kbh. I95 I, s. 9I). 